\title{
Power to the people: local energy initiatives as seedbeds of innovation?
}

\author{
Maarten Arentsen ${ }^{*}$ and Sandra Bellekom
}

\begin{abstract}
Background: Two decades after the launch of Local Agenda 21 in Rio de Janeiro, we have witnessed the emergence and development of local initiatives in sustainable development. Local energy communities are a clear manifestation of this development. The questions the paper raises are as follows: can local energy initiatives be considered seedbeds of innovation? If so, how can such initiatives lead to innovations in the energy supply?

Methods: We applied desk research and reviewed secondary literature.

Results: The questions are answered empirically and theoretically. Empirically, the paper analyses the causes and manifestations of local community initiatives throughout Europe and especially in the Netherlands, to discover the drivers and foci of the initiatives. Theoretically, the paper provides an institutionally oriented classification of local electricity initiatives, based on coordination, technology and performance. In a final step, the paper analyses the innovative capacity of the local energy initiatives.

Conclusions: The conclusion is that local electricity initiatives can be considered a seedbed of innovation but with no potential to develop dominance in the electricity supply. The local initiatives will develop as niches inside the dominant central generating station electricity system and will add to the hybridisation of its products and services.
\end{abstract}

Keywords: Bottom-up innovation; Local energy initiative; Renewable energy; Seedbed of innovation

\section{Background}

Twenty years after the Rio conference on sustainable development, two things have changed dramatically: climate change has replaced sustainable development as the Grand Societal Challenge, and bottom-up innovation dynamics have developed in response to top-down failure [1]. In Europe, the latter change clearly reflects the importance and significance of chapter 28 of Agenda 21, which states that local authorities 'play a pivotal role in educating, mobilizing and responding to the public to promote sustainable development' [2]. But the dynamics of change went beyond local authorities. Throughout Europe, local initiatives in neighbourhoods, villages and cities have independently adopted the adage think globally, act locally'. Numerous local initiatives focusing on climate change/sustainable development have developed in the aftermath of the Rio conference, and they are still

\footnotetext{
* Correspondence: m.j.arentsen@utwente.nl

School of Management and Governance, Twente Centre for Studies in Technology and Sustainable Development (CSTM), Institute for Innovation and Governance Studies (IGS), University of Twente, P.O. Box 217, Enschede $7500 \mathrm{AE}$, The Netherlands
}

developing, such as those devoted to energy in the UK [3]. The many local initiatives everywhere in Europe support the hypothesis that civil society and grassroot social movements, in particular, are important carriers of sustainability transitions. Part of the hypothesis developed here is that local groups have the ability to develop innovative social practices which are influencing change in wider cultural norms [4]. Ornetzeder and Rohracher [5] provide support for this hypothesis while analysing early initiators of local wind power, solar heating and car sharing, encouraging innovations in those fields. Locally, therefore, the initiative lies not only with the authorities but also with independent individuals and groups. It thus makes sense to focus on bottom-up innovation and transition dynamics initiated by local groups, associations and organisations, to get a better understanding of the heritage of the Rio Summit on local sustainable development.

\section{Methods}

One of the intriguing questions in this respect is whether the local initiatives can indeed be considered a

\section{Springer}


seedbed of innovation for sustainable development and, if so, how. Do local initiatives really have an impact on the dominant energy practices in society? Here, we investigate this question for the local initiatives concerned with sustainable or renewable energy. Our core questions are as follows: Are local energy initiatives seedbeds of innovation? If so, how do such initiatives produce innovations in the energy supply? Exploring these questions is important for the governance of energy and climate in cities. The rise of renewable energy technologies into the energy system also seems to affect the current organisational structure of the system. One manifestation is the increasing involvement of communities in, for instance, electricity production. Due to distributed generation (solar panels), communities are getting more involved in electricity production and supply. They want to organise and manage supply and demand at the community level and, in this way, nominate themselves as participants in the governance of energy and climate in cities. The aim of the paper is to explore if and how the local initiatives could make a difference in innovating the energy system, in particular, electricity supply. Sustaining electricity supply is very important from a climate protection perspective and one of the drivers of energy communities (see below). The local initiatives and community's outlook, organisation and activities are theme in the literature. The analysis of their innovative potential is hardly theme of research. This paper wants to contribute to the knowledge on the innovative potential of local communities in electricity supply.

The paper is structured in the following way. The first subsection briefly analyses reasons for the rise and development of local energy initiatives in Europe. Based on a literature study of recent scientific and non-scientific literature, we categorise the causes in four types. The next subsection describes some of the current manifestations of local energy initiatives. A selection of large and small initiatives is analysed with respect to their origin, motives, structure and innovative activities. After these more empirically oriented subsections, the third subsection provides some theoretical understanding and systematisation is included. The institution-technologyperformance triangle found in the institutional literature is applied to understand the position of local energy initiatives with respect to other energy systems. The last subsection analyses the innovative impact of the initiatives and answers the question of innovative seedbeds. The contributions of the local energy initiatives to the aspects Schumpeter relate to innovation are researched. After the conclusion that the initiatives are innovative, we continue by studying the possible influence of these innovations on changing the energy system.

\section{Results and discussion Causes}

The emergence of local energy initiatives appears to be closely related to the emergence of other local initiatives (not only geographical but also based on connectivity, common interests) aimed at 'doing things ourselves'. It appears that we no longer trust organisations (large multinationals and governments) to grow, trade and prepare our food (community gardening, (vers)voko, potluck dinners, local (organic) markets, neighbourhood orchard), take care of our neighbourhood ('opzomeren', buurtwachten), trade our consumption (we-economy), finance our initiatives (crowdsourcing), control our insurance (broodfonds), sustainably run the society we live in (eco-villages), provide us with (clean) energy (local energy initiatives, winddelen, windvogel) and so on. All these things can be done by individuals: we can grow our own vegetables in the garden, clean the sidewalk in front of our house, install PV panels on our roof, and live more sustainably. However, there seems to be a growing interest in doing these things collectively. Being part of a community is becoming more important to us: '... many "sustainability oriented" social movements explicitly have "localism" as a core issue' [4].

A wealth of literature exists on the motives, drives and barriers to the emergence of local energy initiative. Among others, Bomberg and McEwen [6] studied the drives of communities to participate in local energy initiatives. They distinguish 'structural' and 'symbolic' resources. The first relates to political structures, while the second consists of non-material incentives, with community identity and autonomy being highlighted. As expected, support from the government helps to realise local initiatives. However, the capability of the local group to reach and use this support is also important. Another influential factor is the closed energy sector. This could be a barrier but can also be a driver when groups wish to be independent of the existing energy companies. In the Netherlands, Boon [7] analysed the importance of a long list of possible influences on the emergence, perception, acceptance and support, and operating technology of local energy initiatives. Important factors that lead to the emergence of an opportunity to initiate a local energy initiative are energy prices, environmental awareness, independence of large companies and exporting countries, possible local sources, such benefits as a green image and social cohesion, and dissatisfaction with inconsistent energy policies and incompetent governments. According to Chin-A-Fo [8], care for the environment and independence of large energy companies are the two main drivers of participation in a local energy initiative.

The majority of these motives can be categorized into four types of motive: environmental, economical, dissatisfaction with government effectiveness, and social. Concerns for the environment and a sense that society is 
going the 'wrong' direction drive many local initiatives. Rogers et al. [9] questioned and interviewed the participants in a sustainable energy community in the UK. The most frequently mentioned reason for becoming involved in the project was the environment. However, besides interest in environmental issues, economic aspects also frequently played a part. Becoming independent of large energy companies, adding local value, creating jobs and profit in the region, as well as profit for individual households, are reasons to set-up or join a local energy initiative. According to Boot [10], local movements focus on reducing the added value flow outside of the local region, keeping it in the community. A general distrust of government solutions and measures aimed at actually reducing the environmental impact of our society are also motivators for people to take the initiative themselves, both individually and in local cooperatives. Finally, social drives can be distinguished. An increasing desire to strengthen community identity and to become autonomous is what Bomberg and McEwen [6] call 'symbolic resources', which drive communities to participate in local energy initiatives. A growing sense of community can be observed in society, with local groups emerging in several different fields. Most initiatives are based on a combination of these four types of drive.

To summarise, we see a growing awareness and concern for the environment and the influence of energy use and generation thereon; an interest in social cohesion; independence of large (energy) companies; and a distrust that the government will solve our environmental problems. All of which are reasons for the establishment of local energy initiatives. Besides these aspects, it is also important to note that technological improvements have made energy technology (such as photovoltaic panels) available that is reliable, visible, proven and has an acceptable payback time. It is for this reason that the first local energy initiatives have proved successful, so the government steps back [11].

\section{Manifestation}

Several kinds of initiatives have emerged in recent decades. We can see bottom-up movements of people who start by changing their own situation, examples being eco-villages and transition towns. Others start up their own local energy cooperation, examples being Grunneger power and Texel Energie. Another movement is not locally based but involves groups of people with a similar interest, two of these being winddelen and Windvogel. While these initiatives find their roots in the local community, local governments also encourage and set up local energy initiatives. For instance, the Dutch province of Overijssel organised a competition to encourage local sustainable initiatives. The winning village received financial support from the province, but all other participating villages also benefited from the knowledge they gained during and after the competition. Dutch towns and villages are making plans to become sustainable or energy neutral; Groningen wants to be energy neutral in 2035; Wageningen aims to become climate neutral in 2030; and Vasse is taking initiatives to become a sustainable village. Environmental organisations, too, like Milieudefensie (Friends of the Earth Netherlands) are activating their supporters to contribute to the energy transition, in both practical terms as well as in discussions.

A number of example initiatives will further illustrate the manifestations. We selected these initiatives to cover a broad range of actions from initiatives that have grown to worldwide networks but also initiatives which remained at a more local scale of a municipality, will be covered. The selection includes both geographical localised and virtual communities. Well-known and less-known initiatives are considered and projects with different types of initiators. This has resulted in six selected examples which are discussed below.

\section{Ecovillages}

The object of an ecovillage is to create a sustainable community. The focus is on social, ecological and spiritual dimensions [12], but economic development is also included $[13,14]$. A word-wide network of such initiatives started in 1995 in the UK after a conference with the theme 'Ecovillages and Sustainable Communities' [15]. Research by Kasper [16] has shown that energy conservation and renewable energy production often form part of the intentions of an ecovillage. Currently, eight Dutch ecovillage initiatives are members of the Global Ecovillage Network, most of them having started only a few years ago [17]. Many different types of ecovillage initiatives exist; the initiatives in the Netherlands seem to focus mainly on community building. A notable exception is the ecovillage initiative in Brabant, among the aims of which is the production of their own green energy and autonomy [18].

The attitude of ecovillages towards energy could eventually lead to an autonomous energy system. However, at present, most ecovillages seem to be connected to the central grid. They focus closely on the local scale; food and energy production is attuned to the village's actual natural surroundings. Energy generation equipment can be community owned, as in the Three Groves Ecovillage [19] but apparently this is not always the case.

The innovative power of ecovillages is visible in the communities that have been built. Jackson [15] describes how ecovillage initiatives diffuse: 'Many ecovillage principles are beginning to influence traditional town planners, such as peripheral parking, common community facilities and central open spaces without fences'. Also, Dawson [20] sees the potential of innovations: '... ecovillages are in 
the forefront of exactly those types of applied research, demonstration and training that will be required in the transition: saving seeds, developing place-specific technologies for growing food, energy-efficient housing, energy-generation and so on'. Dawson observes that there is a (slow) trend to becoming more closely embedded in the surroundings, besides the more traditional targeting of people with similar interests. He considers this shift essential for ecovillages to survive and contribute to the transition to a more sustainable society.

\section{Transition towns}

While Ecovillages tend to be newly built villages, grouping people together geographically, the residents of Transition Towns (TT) generally live more widespread from each other [21]. Rob Hopkins founded the TT movement in 2005 in Totnes and the initiative quickly spread around the world, despite the obstacles experienced [22]. The movement focuses on a transition towards a society in which people, resilience and biodiversity are important [23]. The residents want to face problems related to our energy supply, economy and climate [24].

In the Netherlands, too, many TT groups have emerged. Although only a limited number of Dutch TT initiatives became members of the international TT Network [25], the national network involves a much larger number [23].

Since climate and energy problems are among the motives underlying the $\mathrm{TT}$ initiative, many activities relate to the local production of renewable energy and energy conservation. Some TT groups cooperate with local energy companies/initiatives, others organise meetings informing the participants of such possibilities as are available. Most TT groups are not clustered in separate neighbourhoods; the members deal with energy in a private context.

In a recent paper, Seyfang and Haxeltine [26] analysed the innovative power of the TT movement based on strategic niche management. They found that TT communities are successful in replicating their concept, but upscaling is difficult; TT ideas seem to have started percolating into the wider society. TT innovations are more social than technical.

\section{Grunneger power}

Local energy companies have been operating for a long time everywhere in the world. However, local energy companies have only recently been set up in the Netherlands. Most such initiatives are based on citizens' idealism; the challenge is to create a successful business [27].

Currently, Grunneger Power only encourages its members to install PV panels, they have no generating units of their own. The ideal is to obtain locally produced power but that ambition has not been achieved at the time of writing [28]. A local, autonomous grid is not envisioned. The cooperation does not aim to maximise profit; returns will be reinvested.

Frans Stokman, associated with Grunneger power, is convinced that such initiatives will change the energy system $[29,30]$. Although the cooperation has had to deal with several problems, it continues to grow [31-34]. The main innovative power of the local energy cooperation inheres in the social, not in the technical aspects [35].

Winddelen For people who want to produce their own renewable energy but are unable to do so in their own surroundings, the Windcentrale initiated 'winddelen' [36]. A wind turbine is financed using crowd funding. Wind turbine shares can be bought, and the purchaser's share in the turbine's output is subtracted from the annual energy consumption. This initiative has turned out to be rather successful [37]; the two selected wind turbines were sold within months, and more interested people have been placed on a waiting list [38].

The wind turbines are simply connected to the central grid; they are not necessarily sited locally. The facility to balance the energy product of the shares with the shareholder's annual electricity consumption is financially attractive, but is not as profitable as own production, since energy taxes and network costs still have to be paid [39]. The taxing of energy that a person produces, but not on his/her own roof, is often seen as hampering the energy transition, for example, [40]. This aspect is also a hindrance to the exchange of locally produced energy, which Grunneger Power would like to achieve. Members of Winddelen form a not-for-profit cooperative. The Windcentrale facilitates this cooperation and is paid for doing so [41].

Winddelen is not innovative in a technical sense but rather in an organisational and financial sense. The wind turbine technology is unchanged, but a new financial instrument was created to allow households to obtain their own wind energy and to balance that financially with their annual power consumption.

\section{Groningen energy neutral}

In common with many municipalities, Groningen also wants to become an energy neutral city. Municipalities all over the Netherlands are attempting to become more sustainable, produce green energy and promote energy conservation. Groningen started in 2006, the original plan being energy neutrality in 2025 , but that goal had to be shifted to 2035 [42]. A municipality can make policy, inform its citizens, facilitate innovative financial and organisational constructions and, of course, should set an example by making its own organisation energy neutral. All these aspects form part of the implementation in the municipality of Groningen, which defends the choices made and focuses adopted [43]. In concrete terms, a wind 
map was developed, showing possible locations for wind turbines [44], and a symposium was organised for entrepreneurs in the energy field [45].

The goal of this initiative is to promote the energy transition within a municipality. Although the municipality will encourage the production of renewable energy, it will not build and own the facilities involved.

Municipalities contribute to the national energy transition by developing their own strategy; they no longer wait for the government to lay down the rules. These local initiatives represent a shift in perceived responsibilities.

\section{Dutch environmental NGOs}

Four Dutch environmental non-government organisations (NGOs) involve their members in a discussion on a national energy agreement [46]. They polled their followers to contribute to the negotiations with the Social and Economic Council of the Netherlands (SER) [47,48]. The response rate was 10\% [49]. The majority of the supporters of the environmental NGOs want to do their bit, although they consider the government should be the party to encourage the energy revolution $[50,51]$.

This initiative is different from the previous ones in the sense that it does not itself deal with the actual production of power. The nationwide energy plan offers chances for local energy initiatives as well as for the (installation) industry [52,53].

Collaboration between the environmental NGOs, the government, the energy business and other stakeholders to achieve a national energy plan represents a new way to reach an agreement. Never before have environmental NGOs been directly involved in defining a new government plan to guide the energy transition in the Netherlands for many years to come.

The local initiatives described in this section are examples of the wide range of local initiatives, movements and organisations in the field of sustainable development. The motives for their establishment differ, but they all share a common concern about the quality of the environment, the large scale organisation and management of many economic functions, waste in energy usage and materials, and a drive to regain responsibility for the quality of life. Environmental concern, climate change and sustainable development are the underlying drivers that make people not only concerned about the future but also highly inventive and innovative in responding to the concerns. Participants come up with new modes of organisation and participation, new modes of energy production, new products and services, and new community-based financing schemes. In the field of energy production and consumption, local initiatives initiate new modes of production and consumption with the help of small-scale renewable energy technology and by organising the local engagement of the population into productive and rewarding business models. We take the local energy initiatives, in particular those devoted to electricity, to study the core question of our paper in greater detail. In the next section, we start by positioning the local energy initiatives more theoretically in the institutional environment of the electricity system.

\section{An institutional positioning of local energy initiatives}

In addition to the empirical understanding of local energy initiatives in the previous sections, this section provides some theoretical underpinnings. Theory is needed to answer the question whether local energy initiatives are seedbeds of innovation or not. Our theoretical reference is the economic institutional literature on network industries in general and the electricity supply in particular [54-57]. In the tradition of this body of literature, network industries - such as electricity, gas, telecom or railways - are analysed from the perspective of institutional organisation, technology and performance. Three different types of institutional coordination are distinguished: markets, networks and hierarchies [56]. This typology has been suggested as an amendment of the Market-Hierarchy typology developed by Oliver Williamson [58]. Moreover, institutional theory assumes a mutual relationship between the technology and the institutional organisation of the electricity system. If technology changes, there will be consequences for the economic organisation of the system. The same is assumed for changes in institutional organisation with implications for technology [55]. Finally, performance standards refer to efficiency standards, or in the case of Williamson to minimal transaction costs [59]. In other words, the theoretical understanding of local energy initiatives requires them to be linked to the institution-technology-performance triangle in the institutional literature. See Figure 1.

The figure defines the three core dimensions as a three-dimensional space with each dimension representing a continuum between two boundary values. With the help of this scheme, it is possible to position local energy initiatives theoretically vis-à-vis other energy systems, in particular the central station electricity system, which is the dominant configuration in the electricity supply system. We therefore start by classifying the current central station electricity system in the triangle of our classification scheme, which shows that the institutional organisation of the central system is integrated, meaning that all necessary components are present for the system to function well [60].

Before liberalisation, the functions were organised according to a hierarchical type of institutional coordination (monopoly). Liberalisation turned the institutional design into a market-based type of coordination. However, in both institutional models, the positions and functions are integrated. The core of the central station electricity system is the technological system with the 


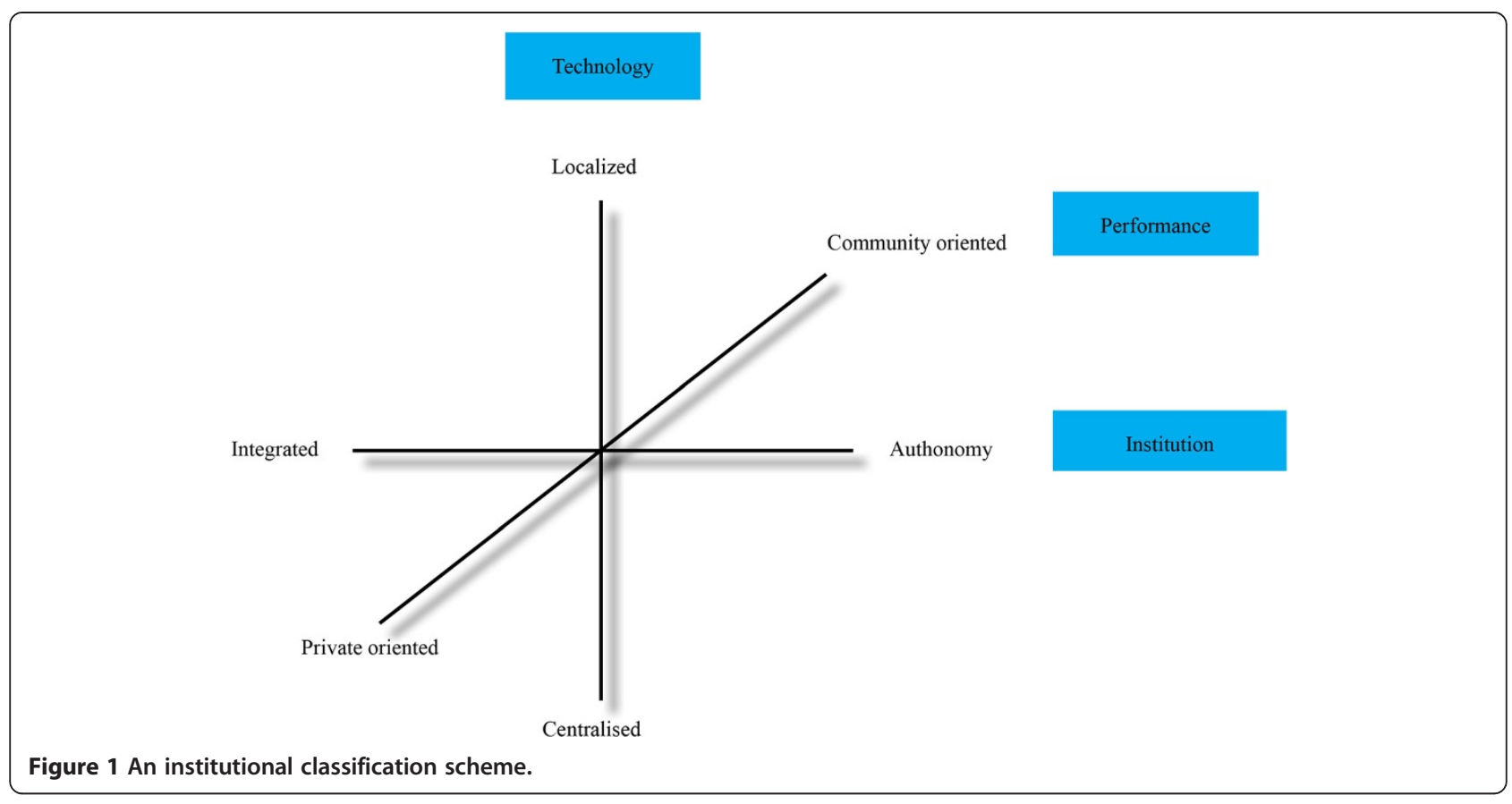

production units, and the grid for connecting them with the load centres. No matter what the energy resources may be (fossil, hydro, nuclear or renewable), the technology is large in scale and centrally managed by the grid. Finally, the performance of the central station electricity system is privately oriented since the introduction of liberalisation. The benefits of both supply and demand are privatised [60,61].

Looking at the local initiatives in relation to this positioning of the central station electricity system, it can be seen that such initiatives appear to be quite the opposite of the central station electricity system. The local initiatives are institutionally autonomous, referring to the diversified local types of coordination with participation as a core feature [62]. They chose their own type of coordination, and they organise membership and participation in their own way. The performance is community oriented and not privatised, as in the case of the central station electricity system. Local initiatives perform for the benefit of the neighbourhood, the community, the village or the city. Performance, therefore, is predominantly community oriented [63]. Finally, technology deviates greatly from the central station system. The technology is small scale and localised, despite the connection to the grid. Localisation of production technology can be geographically localised or community/ownership oriented. Quite often the community ownership of production technology lies at the heart of the local organisation, with sustainable optimization of local production as joint ambition and target. The grid connection is basically considered a necessity for back up reasons, when local production does not yet permit autarchy. In other words, the local energy initiative in its purest form can be considered institutionally as the opposite of the dominant centralised electricity system. The initiatives are part of the dominant system but at the same time, are rather different in their coordination, organisation, technology and performance.

Besides both extreme models (the centralised model and the localised one), Figure 1 also allows one to distinguish all kinds of intermediate models. Some examples are given in Figure 2. The lower left and the upper right quadrant of the figure display both extreme models: the current centralised electricity system and the independent local, small scale electricity system. Hybrid models are displayed in the upper left and bottom right quadrant of the figure. Both hybrids show a mixture of local and central, on both institutional and technological dimensions. The PV project of an energy company is a good example of localised technology that is institutionally integrated in the centralised electricity system. The performance is a mixture of gains for households owning the PV panels and the energy company. The household gain is a reduced electricity bill after repaying the cost of the panels, and the company gain is customer binding and the continued sale of backup electricity in addition to the autonomous production of the PV owners.

The local energy association is an example of a localised institutional organisation combined with centralised technology and a mixture of performance gains. The local energy association is a local organisation that contracts electricity on the open market for a local community. The community gains are a decent electricity price, while the gain for the company is the profitable supply contract. Quite often the local energy association is the 


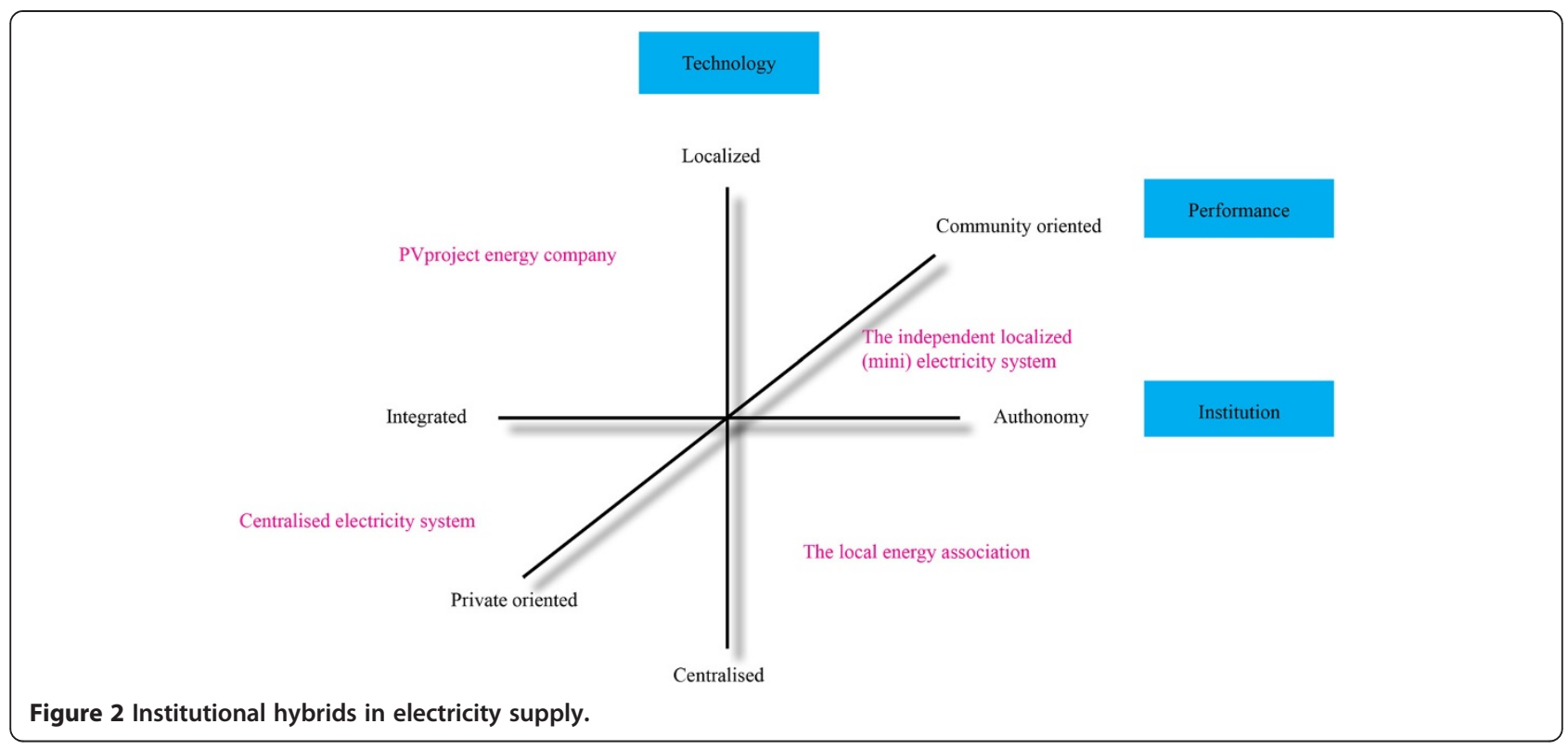

first step in a process to establish an autonomous localised energy system. As shown in the previous section, several locations inside and outside the Netherlands share this ambition $^{\mathrm{a}}$. This shows that the three-dimensional institutional space is helpful in tracing and classifying hybrid types of local energy initiatives, combining the features of the central station electricity system and the local energy initiatives.

Now we have positioned the local energy initiatives theoretically, in the next section, we turn to the question of the innovative nature of the local initiatives.

\section{Local energy initiatives as seedbeds of innovation?}

Answering the question posed by the title of the paper and this section requires an understanding of the notion of innovation. We draw on the seminal work of Joseph Schumpeter, who developed the modern notion of innovation [64]. According to Schumpeter, innovation denotes the introduction of five kinds of new approaches by entrepreneurs: new products, new production processes (technologies), new markets, new organisations and new input [65]. Schumpeter basically defined innovation in terms of new combinations of existing resources [66]. He viewed innovation as part of a trilogy of change: invention, innovation and diffusion [67]. Invention is conceived as the generation of new knowledge and ideas, whereas innovation refers to the transformation of inventions into new products and processes. Diffusion, finally, refers to the spread of these products and processes into the economic process. Innovation, therefore, can affect both technical and non-technical phenomena. Whereas Schumpeter concentrated on technological and non-technical innovations and the implications for economic development, innovation can also address the social sphere [68].

In the context of the Schumpeterian understanding of innovation, the local energy initiatives can be considered as Schumpeterian entrepreneurs who came up with new combinations of knowledge and resources related to the electricity supply. They did not develop new knowledge but instead used already existing organisational models and technologies and applied them to the local electricity supply. In this way, the initiatives can be considered as innovations. They developed new ways of organising production and consumption in the electricity supply. For instance, the community as an organisational entity did not exist in electricity production and consumption until it was initiated and pushed by local energy initiatives. Public-private partnerships did exist in electricity production, but the group/community idea was new in the consumer segment. The same holds for the idea of combining electricity consumption with production. This model was already known in the industrial segment of the electricity market but was new for the household segment. The local energy initiatives made households both consumers and producers, with the term prosumer coined as new descriptive label. Community gain as a performance standard was also new in the electricity system. Previously, the gain was either collective (under monopoly) or private (under liberalisation) [57]. Thus, local energy initiatives can indeed be considered seedbeds of innovation. They introduced innovations to the electricity system, especially institutional innovations, not so much technological ones. In a way, technology enabled and facilitated local energy initiatives rather than being their product. Innovations in solar PV, wood incineration, bio-digestion and 
wind turbines brought electricity technology closer to local energy initiatives, enabling them to organise local electricity production and consumption for the benefit of the community.

Local energy initiatives innovated in terms of the scale, focus and organisation of electricity production and consumption, and, therefore, the local initiatives indeed can be considered as "seedbed of innovation". But the intriguing question related to this conclusion is where does the seedbed lead to? In other words, what does the innovative capacity of the local energy initiatives imply for the future development of the electricity system? Here, different answers are possible. First, the seedbed could be considered as an incubation to develop from a niche into a dominant electricity regime $[69,70]$, turning the central station electricity system into an alternative system. Second, the seedbed of local energy initiatives could be considered in its potential to affect the future development of the central station electricity system. We will analyse both options in two separate sections.

\section{From niche to dominant regime?}

With respect to the first option, our expectation is that local energy initiatives will continue to develop as niches in the meaning of Geels multi-level perspective of socio-technical transitions [70] on the periphery of the dominant central station electricity system. We advance two arguments for this expectation, technical and institutional.

With respect to the first, technical argument, electricity is a technology-bound product; physics requires that it be produced in real time and consumed in a closed technological system. This has been a core driver in the upscaling of the electricity system throughout its existence. The scale of the system is now European in terms of technology, system management, institutional coordination and organisation. ${ }^{\mathrm{b}}$ The rationale behind the technical upscaling of the system is efficiency and back up [60]. The enormous electricity requirement and its significance in modern society make us very dependent on the large-scale central station electricity system. Nowhere in Europe would the local initiatives be able to cover the electricity demand of modern society. This would not only require huge increases in local production throughout Europe but also the interconnection of all the local production sites. This would once again end up with the present European electricity grid, including its centralised large-scale production units. In other words, a development to replace the current central station electricity system with a European integrated grid would not appear to be very likely in the near future. The combination of huge electricity demand, physics and technology will be the barrier to local energy initiatives coming to dominate the electricity supply.
The second, institutional argument rests on the fact that stakeholders in the incumbent fossil, hydro and nuclear dominated electricity regimes are not interested in a development away from the dominant central station electricity system. The incumbent system is large scale in every respect, including the gains and losses to the incumbent companies and organisations. The sunk costs as well as the asset specificities are vast. In the short term, all incumbents therefore face the risk of loss from the local energy initiatives. Throughout the electricity production chain, there will be a loss of clientele and turnover and an increase of risk and uncertainty. The incumbents' resistance is subtle but effective, as shown by the results of 10 years of energy transition in the Netherlands [71,72].

Both arguments lead us to expect that the local energy initiatives will remain and develop as a niche in the dominant central station electricity system. The niche will develop inside the dominant system for the same two arguments. Local initiatives will need backup from the central grid, and this will cause them to remain part of the dominant system. The interests of the incumbents in the dominant regime will also keep the niche inside the dominant system. Incumbents have an interest in collaborating with the niche players. They might also be forced to collaborate by the ambitions of the local communities. Companies and communities will develop new products and services to benefit both parties, such as electrical car sharing services and smart energy system development. Therefore, the most dynamic developments will lie in the central area of Figures 1 and 2 above, rather than in the upper right quadrant of the figures. The upper right quadrant will be the space where the purely localised energy system will develop. This model might be particularly interesting for rural communities in Europe. Triggered by nearby bio-resources in combination with robust conversion technologies, these communities quite often take local renewable energy production as a guide for developing a sustainable community. Examples of these initiatives can be found in Austria, Germany and Switzerland ${ }^{c}$.

\section{Hybridization?}

The second impact option of local initiatives could be a further hybridization of electricity supply. We expect most hybrid dynamics in the central area of Figures 1 and 2, with both incumbents and local communities as collaborating partners. The entrance point of these hybrid types of collaboration is smart grid technology. This kind of technology is beneficial to both the local communities and the incumbent companies. Smart grid management technologies allow demand-side management and peak shaving, bringing financial gains to both the local community and the incumbent company, with energy efficiency gains for both. The smart grid technology is only in its infancy but is expected to have huge potential in 
making electricity and gas supply much more efficient [73]. New smart technologies will thus draw together the local communities and the incumbents, to the benefit of a more efficient electricity supply.

A further step in this direction is emerging under the label smart energy systems [74]. And here too, technology and institution as well as performance are involved. See Figure 3. The figure shows that most innovation is expected in the centre of the figure, where the new and the old will meet, causing a further hybridisation of the electricity system. The hybridisation towards smart energy systems is predominantly caused by the large-scale integration of intermittent renewable-based electricity production. In particular, wind- and PV-based electricity generation heavily depends on weather conditions as this requires back-up capacity in case of under production and storage capacity in case of overproduction by the renewables. According to some scholars $[74,75]$, the management of these problems needs an energy focus beyond electricity. Lund et al. (2012) argue and illustrate how gasand heat-based technologies, like CHP and bio-energy, and new renewable-based energy carriers, like hydrogen, can add to efficient and effective balancing of the electricity grid. Those technologies already operational quite often are owned and operated by local communities. Local communities as owners of potential balancing technologies can operate the technology also for balancing purposes and this would innovate their business model and the transactional relationship with the incumbent regime. Lund et al. show how a fully operational local CHP plant not only can satisfy local energy needs but easily also can operate as efficient balancing capacity. The investments for such an additional function of the CHP plant are rather restricted. Local heat pumps, hydrogen and electrical vehicles could operate accordingly. The hybridisation in technology and institution is also affecting the performance dimension in Figure 3. Here, the incumbent regime and the local community are combining their private respectively community orientation in performance with system oriented performance standards, like efficient balancing and sustainability.

This leads us to the conclusion that the local energy initiatives can indeed be considered as seedbeds of innovation. The local initiatives have innovated especially the institutional and performance perspectives of the electricity supply. More importantly, they have questioned the centrality of the dominant regime and its path-dependent development towards ever-increasing scale. Local energy initiatives used the availability of smaller-scale technology in combination with smart grid management technology, to develop new ways of organising the electricity supply to the benefit of the community. The large-scale integration of intermittent renewable-based generation capacity has the potential to add to the innovative power of local communities. Intermittent generation requires balancing technologies which are quite often owned by local communities. It is here where the old and the new meet and jointly design a further hybridisation of electricity supply.

\section{Conclusion}

The aim of the paper was to explore if and how local initiatives could make a difference in innovating the energy system, in particular electricity supply. Sustaining electricity supply is very important from a climate protection perspective and one of the drivers of energy communities. Twenty years after the Rio Summit, we can conclude that local initiatives and activities have taken root. We can observe the rise and diffusion of numerous local initiatives on sustainable development. Our paper has traced and

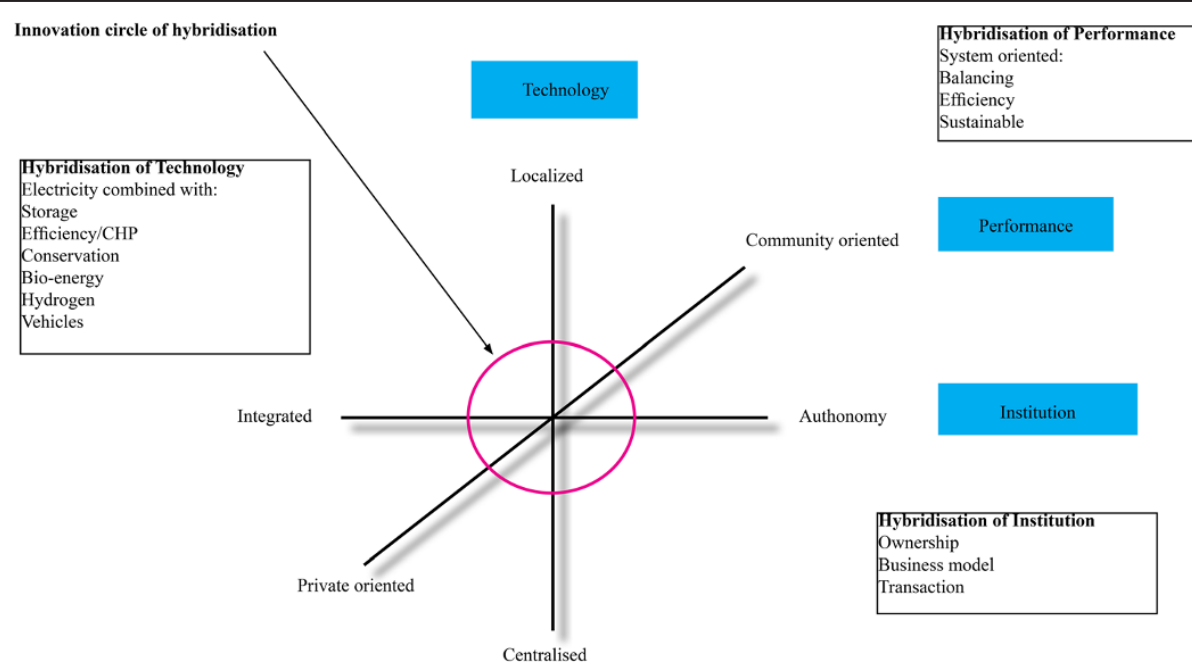

Figure 3 Technology and institution as well as performance involved. 
discussed important drivers, such as environmental concern, local economic development, strengthening social cohesion and disappointment with centralised government coordination. The paper has also given several examples of local initiatives, showing that the initiatives share a wide concern about the future state of the world and the ambition to make a difference by local action. With respect to focal point and orientation, the initiatives vary: some are broader in their orientation than others. From our empirical account, it can be concluded that the local initiatives share the ambition to regain control of certain aspects of life and the need to share this ambition with others in communities of people, either living close to each other or sharing common ideas and ambitions at distance.

The paper then went on to analyse the theoretical grounding of the local initiatives, especially initiatives in the field of renewable energy production and consumption. Focusing on local energy initiatives enabled us to link them with institutional theory on network industries (electricity, gas, ICT, rail). With the help of a threedimensional space, it was possible to understand the local energy initiatives as the opposite of the central station electricity system which has dominated electricity production and consumption almost from the invention of electricity. Institutionally, the local energy initiative is autonomous in coordination, whereas in the dominant electricity system coordination is integrated. Technology is centralised in the dominant system but localised in the local energy system. A major difference also exists with respect to performance, which is individualized in the dominant system, but community oriented in the localised one.

The final step was to answer the core question: Are local energy initiatives seedbeds of innovation or not? Drawing on Schumpeter's notion of innovation, we have concluded that the local energy initiatives can be considered seedbeds of innovation. In electricity supply, they have renewed the organisation and coordination of production and supply of electricity, business models and financing schemes. We also concluded that the local innovations will remain a niche in the dominant central station electricity system. We advanced two arguments for this. The paper ended with the expectation that collaboration between local energy initiatives and incumbents will increase institutional hybridization in the electricity supply. Our expectation is that smart grid technology and smart energy systems will function as a mediator between the local and the central system. If smart technology proceeds, the hybridization of the electricity supply will follow. We showed that the further integration of intermittent renewable-based generation capacity adds to the hybridization of electricity supply in terms of technology, institution and performance.
Our analysis shows that local energy initiatives indeed seeded innovation in the electricity system. The local initiatives brought the sustainability standard clearly and actively into the electricity system. Policy could recognize this achievement more openly, for instance by relieving legal and institutional barriers in the further development of local energy communities. For instance, peer-to-peer supply of electricity in the local community is a strong ambition of the energy community but often not allowed by law. The same holds for real-time billing of electricity. Here too, a change of rules could balance the economic interest of the community with the societal interest of a more efficient electricity system. Policy could encourage more actively the potential contribution to grid balancing of locally owned production and storage capacity. The example of Denmark shows that there are quite some societal gains involved if the community-owned production capacity is recognised and used for balancing purposes. The same holds for local storage capacity. Recent research in Germany showed the economic and environmental advantages of investing in local balancing and storage capacity over investments in enlargement of the peak tolerance of the distribution grid [76].

The innovation in and hybridization of electricity supply require a different role of policy. In the pre-liberalisation era, this role was basically planning oriented and became regulation oriented under liberalisation. It shows that the dynamics in the electricity system, stemming from the integration of renewables, the balancing problems and the emergence of local energy communities, require innovative policy. Such a policy should address the problem of balancing the diversity of interests in the modern electricity system: the interest of the private company, the interest of the local energy community and the societal interest of a cost effective sustainable electricity system.

\section{Endnotes}

${ }^{\mathrm{a}} \mathrm{A}$ nearby example is the initiative south of Enschede to establish and run an energy company in the region called Achterhoek (www.AGEM.nu).

${ }^{\mathrm{b}}$ This is not to say that the EU electricity market is one single internal entity.

${ }^{\mathrm{c}} \mathrm{See}$ for instance the projects on renewable energy in the project survey on the website of Intelligent Energy Europe and the participants list on the website of the European Energy Award.

\section{Competing interests}

The authors declare that they have no competing interests.

\section{Authors' contributions}

MA developed the concept and designed the study; he embedded the empirical results in a theoretical framework and analysed the innovativeness. SB carried out the empirical research. Together, they drafted the manuscript. Both authors read and approved the final manuscript. 
Received: 5 September 2013 Accepted: 18 December 2013

\section{Published: 14 January 2014}

\section{References}

1. Fraser EDG, Dougill AJ, Mabee WE, Reed M, McAlpine P (2006) Bottom up and top down: analysis of participatory processes for sustainability indicator identification as a pathway to community empowerment and sustainable environmental management. J Environ Manage 78(2):114-127

2. Lafferty WM (ed) (1999) Implementing LA21 in Europe. New initiatives for sustainable communities, ProSus, Oslo

3. Seyfang G, Park JJ, Smith A (2012) Community Energy in the UK. Science, Society and Sustainability (3S) Research Group, School of Environmental Sciences. University of East Anglia, Norwich

4. STRN (2010) Civil society, culture and social movements in transition. In: A mission statement and research agenda for the sustainability transition research network. pp 12-13, (http://www.transitionsnetwork.org/files/ STRN_research_agenda_20_August_2010\%282\%29.pdf), report of the steering group of the STRN

5. Ornetzeder M, Rohracher H (2013) Of solar collectors, wind power, and car sharing: comparing and understanding successful cases of grassroots innovations. Global Environ Change 23(5):856-867

6. Bomberg E, McEwen N (2012) Mobilizing community energy. Energy Policy 51(0):435-444, http://dx.doi.org/10.1016/j.enpol.2012.08.045

7. Boon FP (2012) Local is Beautiful: The emergence and development of local renewable energy organisations. Utrecht University, Thesis

8. Chin-a-fo H (2012) Nieuwe nuts, lokaal energie opwekken. NRC Handelsblad, NRC Media, Amsterdam, pp 28-29

9. Rogers JC, Simmons EA, Convery I, Weatherall A (2008) Public perceptions of opportunities for community-based renewable energy projects. Energy Policy 36(11):4217-4226, doi:10.1016/j.enpol.2008.07.028

10. Boot P (2012) Lokale initiatieven in opmars - Planbureau voor de Leefomgeving. Energie Actueel, Vereniging Energie-Nederland, Den Haag

11. Amsterdammer DG (2012) Do It Ourselves, als antwoord. De Groene Amsterdammer, Amsterdam

12. Joseph L, Bates A (2003) What is an "Ecovillage"? A Journal for Cooperative Living, Rutledge, MO, Communities

13. Jackson H (1998) What is an Ecovillage? In: Gaia Trust Education Seminar Thy, Denmark, September 1998

14. Jackson R (2006) Global Economics-There IS an Alternative. Paper presented at the Denmark's Social Forum, Copenhagen, 03-05 February 2006

15. Jackson R (2004) The ecovillage movement. Permacult Mag 40:25-30

16. Kasper DVS (2008) Redefining community in the ecovillage. Human Ecol Rev 15(1):12-24

17. Global Ecovillage Network (2013) Connecting communities for a better world. http://gen.ecovillage.org/. Accessed 30 May 2013

18. Ecovillage Brabant (2013) Ecodorp Brabant, leven in verbinding. http://www. ecodorpbrabant.nl/english/. Accessed 30 May 2013

19. Three groves ecovillage. this is value. http://threegrovesecovillage.com/thisis-value. Accessed 10 June 2013

20. Dawson J (2006) Are ecovillages a solution to the coming energy famine? Permacult Mag 47:47-48

21. Sevier L, Henderson M, Naidu N (2008) Ecovillages: a model life? Ecologist 38(4):36-41

22. Smith A (2011) The transition town network: a review of current evolutions and renaissance. Social Mov Stud 10(1):99-105, doi:10.1080/ 14742837.2011.545229

23. Transition towns Nederland (2013).... netwerk van transitie steden in Nederland. http://transitiontowns.nl/. Accessed 31 May 2013

24. Connors P, McDonald P (2011) Transitioning communities: community, participation and the transition town movement. Comm Dev J 46(4):558-572

25. (2013) Transition network. http://www.transitionnetwork.org/. Accessed 31 May 2013

26. Seyfang G, Haxeltine A (2012) Growing grassroots innovations: exploring the role of community-based initiatives in governing sustainable energy transitions. Environ Plann C: Govern Policy 30(3):381-400

27. van den Bersselaar D (2013) Lokale duurzame energie een succes?. http:// creatingtomorrow.com/lokale-energie-succes-voor-burgers-of-bedrijven/. Accessed 31 May 2013

28. Grunneger Power (2013) Energie in eigen hand. http://www. grunnegerpower.nl/index.php/component/content/article/135. Accessed 10 June 2013
29. Stokman F (2012) Energierevolutie begint lokaal. Leeuwarder Courant. NDC mediagroep, Leeuwarden

30. Stokman $F$ (2012) The revolution in energy production is beginning at local level. http://www.rug.nl/news-and-events/people-perspectives/opinie/2012/ 37fransstokman. Accessed 26 April 2013

31. Poelman F (2013) Afblazen nu erg ongelukkig. Dagblad van het Noorden, NDC Mediagroep, Groningen

32. Poelman F (2013) Energiecoöperatie richt haar ogen op de toekomst, Dagblad van het Noorden. NDC Mediagroep, Groningen, p 11

33. Poelman F (2013) Grunniger Power is 75 mille kwijt, Dagblad van het Noorden. NDC Mediagroep, Groningen, p 9

34. Poelman F (2013) Noordelijk Energiebedrijf staat op losse schroeven. Dagblad van het Noorden, NDC Mediagroep, Groningen

35. Stokman F (2012) Positieve sociale effecten. Dagblad van het Noorden, NDC Mediagroep, Groningen

36. de Rooy M (2012) Energie uit je eigen stukje windmolen. Het Financieele Dagblad, FD Mediagroep, Amsterdam

37. Bremmer D (2012) Veel burgers investeren in windmolens, Algemeen Dagblad. AD NieuwsMedia, Rotterfam, p 19

38. RTL nieuws (2012) Bezuinigen op energie met eigen windmolen. http:// www.rtl.nl/components/actueel/rtlnieuws/2012/12_december/25/ binnenland/bezuinigen-op-energierekening-met-windmolen.xml. Accessed 30 May 2013

39. Windcentrale (2013) Hoe zit het met de energiebelasting? https://www. windcentrale.nl/faq?faq=78. Accessed 10 June 2013

40. van Tongeren L, Vloermans $P$ (2013) Het belasten van zelf opgewekte stroom slaat nergens op. NRC Handelsblad, Amsterdam, p 12

41. Windcentrale (2013) Hoe verdient de Windcentrale haar geld? https://www. windcentrale.nl/faq?faq=39. Accessed 10 June 2013

42. Gemeente Groningen (2011) Masterplan Groningen energieneutraal

43. Gemeente Groningen (2013) Groningen geeft energie. Muncipality of Groningen, Groningen, http://gemeente.groningen.nl/energie/ MasterplanGroningenEnergieneutraal.pdf

44. Gemeente Groningen (2013) Stad brengt kansen windenergie in kaart. http://gemeente.groningen.nl/energie/stad-brengt-kansen-windenergie-inkaart. Accessed 13 June 2013

45. Gemeente Groningen (2013) Gemeente Groningen houdt symposium over energiebesparing. http://gemeente.groningen.nl/energie/gemeentegroningen-houdt-symposium-over-energiebesparing. Accessed 13 June 2013

46. SER (2013) Energieakkoord. Social and economic council of the Netherlands. http://www.energieakkoordser.nl/. Accessed 31 May 2013

47. Greenpeace (2013) Greenpeace ruilt actieoverall om en onderhandelt in SER voor schone energie. http://www.greenpeace.nl/2013/Persberichten/ Greenpeace-ruilt-actieoverall-om-en-onderhandelt-in-SER-voor-schoneenergie/. Accessed 13 May 2013

48. Milieudefensie (2013) Milieuorganisaties raadplegen achterban over schone energie. http://www.milieudefensie.nl/nieuws/organisatie/milieuorganisatiesraadplegen-achterban-over-schone-energie. Accessed 13 May 2013

49. Onkenhout $H$, van der Veen M (2013) Achterbanpeiling. Ruigrok | NetPanel, Amsterdam

50. De Natuur en Milieufederaties (2013) Resultaat achterbanraadpleging. http:// www.natuurenmilieufederaties.n//DeProvincialeMilieufederaties/Hoofdmenu/ DeNatuurenMilieufederaties/Netwerk/Nieuws/WEBSITE_RESULTAAT_ ACHTERBANRAADPLEGING.aspx. Accessed 31 May 2013

51. Natuur en Milieu (2013) Achterban natuur- en milieuorganisaties wil Nederlandse Energierevolutie. http://www.natuurenmilieu.nl/nieuws/ perscentrum/20130528-achterban-natuur-en-milieuorganisaties-wilnederlandse-energierevolutie/. Accessed 31 May 2013

52. NOS (2013) SER: energieplan nu doorgerekend. http://nos.nl///515772. Accessed 10 June 2013

53. Draijer W (2013) Verantwoordelijkheid. SER. Accessed 10 June 2013

54. Finon D, Midttun A (2004) Reshaping European Gas and electricity Industries. Regulation, Markets and Business Strategies. Elsevier, London

55. Finger M, Groenewegen J, Künneke R (2005) The quest for coherence between institutions and technologies in infrastructures. J Network Indust 6 (4):227-259, 227-60

56. Arentsen MJ, Künneke RW (1996) Economic organization and liberalization of the electricity industry: in search of conceptualization. Energy policy 24(6):541-552

57. Arentsen MJ, Kunneke RW (eds) (2004) National reforms in European gas. Elsevier, London 
58. Williamson OE (1975) Markets and Hierarchies. The Free Press, London, Analysis and Antitrust Implications

59. Mv G (2008) The art of alignment. Transaction cost economics and the provision of public services at the local level. University of Twente, Enschede

60. Hughes TP (1983) Networks of Power. Electrification in Western Society, 1880-1930. John Hopkins University Press, Baltimore

61. Glachant JM (2004) European Electricity Markets: Variety and Integration. In: Finon DaAM (ed) Reshaping European Gas and Electricity Industries, Regulation, Markets and Business Trategies. Elsevier, London, pp 139-183

62. Walkera G, Devine-Wright $P$ (2008) Community renewable energy: what should it mean? Energy policy 36(2):497-500, http://dx.doi.org/10.1016/j. enpol.2007.10.019

63. Blokhuis E, Advokaat B, Schaefer W (2012) Assessing the performance of Dutch local energy companies. Energy policy 45(0):680-690, http://dx.doi. org/10.1016/j.enpol.2012.03.021

64. Schumpeter JA (1934) The Theory of Economic Development. Harvard University Press, Cambridge, MA

65. Lambooy J (2005) Innovation and Knowledge: Theory and Regional Policy. Eur Plann Stud 13(8):1137-1152

66. Fagerberg J (2006) Innovation a guide to the literature. In: Fagerberg J, Mowery D, Nelson R (eds) The Oxford Handbook of Innovation. Oxford University Press, Oxford, pp 1-26

67. Schumpeter JA (1976) Capitalism, Socialism, and Democracy. George Allen \& Unwin Ltd, London

68. Scott-Cato M, Hillier J (2010) How could we study climate-related social innovation? Applying Deleuzean philosophy to Transition Towns. Environ Politics 19(6):869-887, 10.1080/09644016.2010.518677

69. Verbong $G$, Geels $F$ (2007) The ongoing energy transition: lessons from a socio-technical, multi-level analysis of the Dutch electricity system (1960-2004). Energy policy 35:1025-1037

70. Geels FW (2002) Understanding the Dynamics of Technological Transitions, A co-evolutionary and socio-technical analysis. University of Twente, Enschede

71. Hisschemoller M (2008) De lamentabele toestand van het energietransitiebeleid. Observaties en kennisvragen vanuit een interdisciplinair beleidswetenschappelijk perspectief. IVM, Amsterdam

72. Rotmans J (2011) Staat van de Energietransitie in Nederland (draft version). DRIFT, Erasmus University, Rotterdam

73. IEA (2011) Technology Roadmap Smart Grids. IEA, Paris

74. Henrik L, Andersen AN, Østergaard PA, Mathiesen BV, Connolly D (2012) From electricity smart grids to smart energy systems-A market operation based approach and understanding. Energy 42:96-102

75. Frede H, Möller B, Sperling K (2013) Local ownership, smart energy systems and better wind power economy. Energy Strat Rev 1:164-170

76. Nykamp S (2013) Integrating Renewables in Distribution Grids (diss.). University of Twente, Enschede

doi:10.1186/2192-0567-4-2

Cite this article as: Arentsen and Bellekom: Power to the people: local energy initiatives as seedbeds of innovation? Energy, Sustainability and Society 2014 4:2.

\section{Submit your manuscript to a SpringerOpen ${ }^{\circ}$ journal and benefit from:}

- Convenient online submission

- Rigorous peer review

- Immediate publication on acceptance

- Open access: articles freely available online

- High visibility within the field

- Retaining the copyright to your article

Submit your next manuscript at $\gg$ springeropen.com 